\title{
X-ray Crystallography, DFT Calculations and Molecular Docking of Indole-Arylpiperazine Derivatives as $\alpha_{1 \mathrm{~A}}$-Adrenoceptor Antagonists
}

\author{
Wei Xu ${ }^{1}$, Jun-Jun Huang ${ }^{1}$, Bin-Hao Shao ${ }^{1}$, Xing-Jie Xu ${ }^{1}$, Ren-Wang Jiang ${ }^{2}$ and Mu Yuan ${ }^{1, *}$ \\ Received: 14 September 2015 ; Accepted: 16 October 2015 ; Published: 30 October 2015 \\ Academic Editor: Maxim L. Kuznetsov \\ 1 Pharmaceutical Research Center, Guangzhou Medical University, 195\# Dongfengxi Road, \\ Guangzhou 510182, China; xwnail2003@163.com (W.X.); huangjunjun1985@sina.com (J.-J.H.); \\ sbh1539@sina.cn (B.-H.S.); xuxingjie2015@163.com (X.-J.X.) \\ 2 School of Pharmaceutical Sciences, Jinan University, Guangzhou 510632, China; rwjiang2008@126.com \\ * Correspondence: mryuanmu838@sina.com; Tel./Fax: +86-020-8134-0727
}

\begin{abstract}
Indole-arylpiperazine derivatives have exhibited good selectivity for the $\alpha_{1 \mathrm{~A}}$-adrenoceptor, but the structure-activity-binding mechanism relationship remains unclear. In the current study, three compounds (1, 2 and 3) were investigated through single-crystal X-ray diffraction analysis, density functional theory (DFT) calculations and molecular docking using a homology model of the $\alpha_{1 \mathrm{~A}}$ receptor. Compounds $\mathbf{1}$ and $\mathbf{3}$ form H-bonds networks to stabilize their three-dimensional structures, while $\mathrm{C}-\mathrm{H} \cdots \pi$ interactions play a significant role in the packing of 2 . Based on DFT-optimized conformations, the HOMO-LUMO energy gaps and molecular electrostatic potential (MEP) were theoretically calculated at the B3LYP/6-311G (d, p) level of theory. Chemical reactivity increases in the order of $\mathbf{3}<\mathbf{2}<\mathbf{1}$, and the maximum positive region of the MEP maps is mainly localized over the $\mathrm{NH}$ group. The binding mechanisms of ligand- $\alpha_{1 \mathrm{~A}}$-adrenoceptor complexes were illustrated by molecular docking. Binding to Gln177 of the second extracellular loop region via

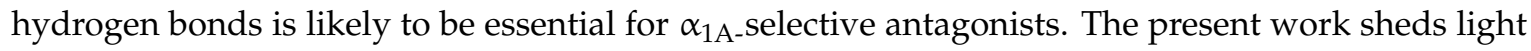
on the studies of structure-activity-binding mechanism and aids in the design of $\alpha_{1 \mathrm{~A}}$ antagonists with high selectivity.
\end{abstract}

Keywords: indole-arylpiperazine; single-crystal; DFT calculations; molecular docking; $\alpha_{1 \mathrm{~A}}$-adrenoceptor

\section{Introduction}

Benign prostatic hyperplasia $(\mathrm{BPH})$ is a progressive condition characterized by a nodular enlargement of the prostate resulting eventually in obstruction of the urethra [1]. BPH affects as many as $60 \%$ of men over the age of 60 and the number of patients is rising worldwide as a result of the aging male population [2]. The disease is characterized by obstructive and irritating symptoms and significantly compromises the quality of life of patients. Estimates of annual pharmaceutical sales of BPH therapies range from \$US 3 to 10 billion, and emerging contenders to current therapies is focusing on drug targets which are able to relax prostatic smooth muscle in a similar way to the $\alpha_{1}$-adrenoceptor $\left(\alpha_{1 \mathrm{~A}^{-}}, \alpha_{1 \mathrm{~B}^{-}}\right.$and $\left.\alpha_{1 \mathrm{D}^{-}} \mathrm{AR}\right)$ antagonists, as this appears to be the most effective mechanism of action [3]. The $\alpha_{1 \mathrm{~A}}-\mathrm{AR}$ subtype is the predominant receptor causing contraction of the prostate smooth muscle and is thought to result in BPH. A potent and $\alpha_{1 \mathrm{~A}}$-selective adrenoceptor antagonist can be an attractive drug candidate for treatment of BPH with fewer undesirable side effects that may be associated with $\alpha_{1 \mathrm{~B}}$ subtype [4].

Arylpiperazine derivatives constitute a class of $\alpha_{1}$-AR antagonists [5-7]. Naftopidil (Figure 1a) is a clinical drug for the treatment of $\mathrm{BPH}$, and this compound reflects the successful application of 
the arylpiperazine skeleton [8]. Several types of these derivatives exhibit high affinity for $\alpha_{1}$-AR in vitro; these compounds include pyridazinone-arylpiperazines [9], arylpiperazine derivatives bearing a flavone nucleus [10], quinazolinone-arylpiperazine [11] and 2-pyridone derivatives of arylpiperazine [12]. Aroyl piperazines can effectively reduce the prostate weights of mature rats in vivo [1]. Our research group also validated that naftopidil-related derivatives are potential multipotent agents that exhibit $\alpha_{1}$-AR blocking activity and antiproliferative activity against human prostate cancer [13]. Thus, considerable attention has been given to the arylpiperazine scaffold in the field of drug discovery because of its unique biological function.

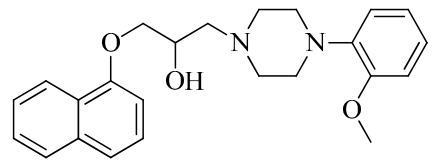

(a)

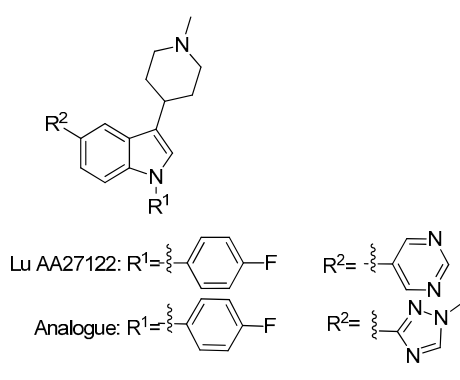

(b)

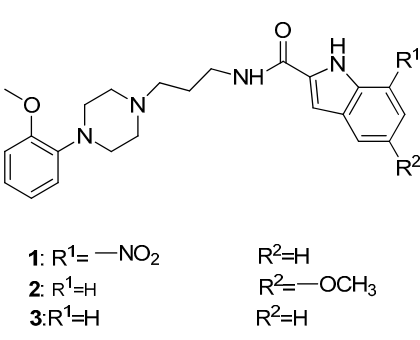

(c)

Figure 1. Chemical structures of naftopidil (a); Lu AA27122 and its analogue (b); and the title compounds 1, 2 and 3 (c).

Agents containing the indole moiety exhibited various biological activities including enzyme inhibition [14,15], tubulin polymerization inhibition [16] and anticancer activity in human HCT116 colon and HepG2 liver carcinoma cells [17]. In particular, pyrimido[5,4-b]indoles were reported to act as the selective $\alpha_{1}$-AR subtypes antagonists [18,19]. Lu AA27122 and its analog (Figure 1b) were identified as high affinity $\alpha_{1 \mathrm{~A}}$-adrenoceptor ligands with $K_{\mathrm{i}}$ values of 0.52 and $0.16 \mathrm{nM}$, respectively [20].

Considering the pharmacological properties of arylpiperazine and indole moieties, our research group successfully designed and synthesized a series of indole-arylpiperazine derivatives. Biological evaluation showed that several compounds exhibit moderately good selectivity for $\alpha_{1}$-adrenoceptor subtypes [13]. However, the structure-activity relationship and the associated with binding mechanisms remain unclear, thereby hindering the design of novel $\alpha_{1 \mathrm{~A}}$-adrenoceptor-selective antagonists.

In this work, crystal structures, geometric parameters and intermolecular interactions of title compounds 1, 2 and 3 were described. Energy gaps between the highest occupied molecular orbital (HOMO) and lowest unoccupied molecular orbital (LUMO) were obtained by theoretical calculations based on DFT-optimized conformations. Molecular electrostatic potential (MEP) was also used to indicate the reactive sites of electrophilic and nucleophilic attacks for these compounds. Molecular docking was then utilized to investigate the binding mechanisms of the ligands- $\alpha_{1 \mathrm{~A}}$-receptor complexes. This work provides valuable information regarding the relationship of structure-activity-binding mechanism, and is particularly beneficial for pharmaceutical chemists.

\section{Results and Discussion}

\subsection{Structural Characterizations}

Compound 1 crystallizes in the monoclinic space group C2/c. The atomic numbering and displacement ellipsoid plot are presented in Figure 2. Crystal data and structural refinement of compound $\mathbf{1}$ are presented in Table 1. Intramolecular H-bonds $\mathrm{C}(10)-\mathrm{H}(10 \mathrm{~A}) \cdots \mathrm{O}(3)$ and $\mathrm{N}(4)-\mathrm{H}(4) \cdots \mathrm{O}(2)$ result in the formation of non-planar and planar six-membered pseudo rings, respectively. The dihedral angle formed between aromatic plane and indole ring is 
$44.20(6)^{\circ}$. The piperazine moiety displays a typical chair conformation, as the torsion angles of $\mathrm{N}(2)-\mathrm{C}(18)-\mathrm{C}(10)-\mathrm{N}(1)$ and $\mathrm{N}(2)-\mathrm{C}(16)-\mathrm{C}(21)-\mathrm{N}(1)$ are is $-58.6(2)^{\circ}$ and $58.7(2)^{\circ}$, respectively.

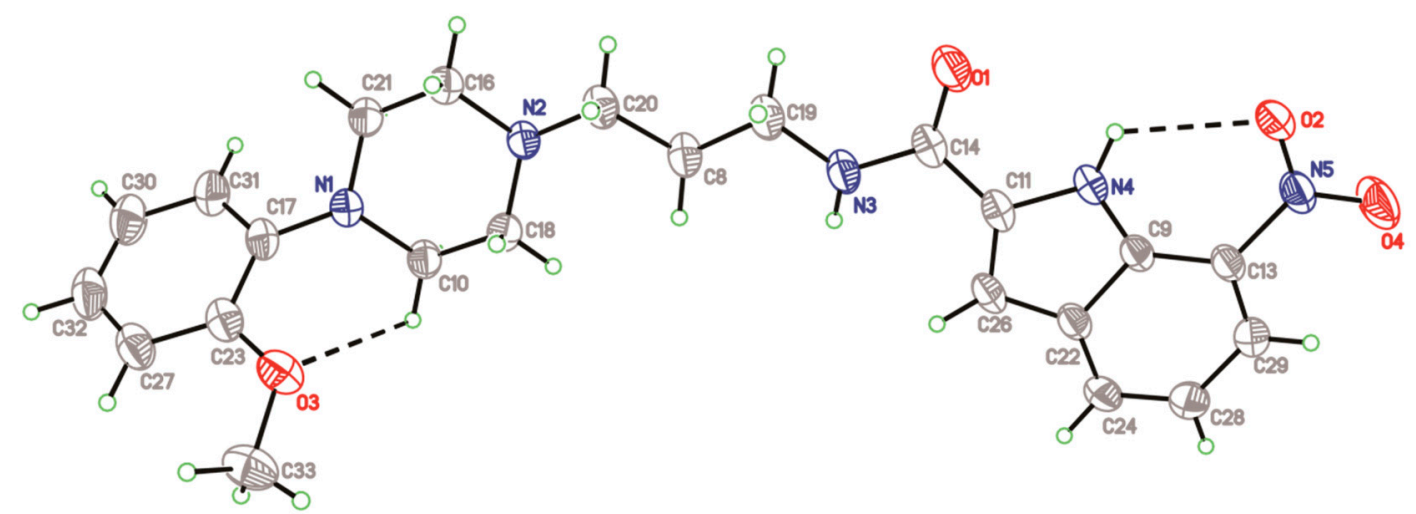

Figure 2. Crystallographic structure of compound 1. Displacement ellipsoids are drawn at the 30\% probability level, and intramolecular hydrogen bonds are presented in dashed lines.

Table 1. Crystal data and structural refinement of compound 1, 2 and 3.

\begin{tabular}{|c|c|c|c|}
\hline Empirical Formula & $\mathrm{C}_{23} \mathrm{H}_{27} \mathrm{~N}_{5} \mathrm{O}_{4}$ & $\mathrm{C}_{24} \mathrm{H}_{30} \mathrm{~N}_{4} \mathrm{O}_{3}$ & $\mathrm{C}_{23} \mathrm{H}_{28} \mathrm{~N}_{4} \mathrm{O}_{2}$ \\
\hline Formula weight & 437.49 & 422.52 & 392.49 \\
\hline Temperature (K) & 293(2) & $293(2)$ & $293(2)$ \\
\hline Crystal system & monoclinic & Triclinic & orthorhombic \\
\hline Space group & $C 2 / c$ & $P-1$ & Pccn \\
\hline a, b, c $(\AA)$ & $\begin{array}{c}21.385(4), 7.8960(16), \\
28.227(6)\end{array}$ & $\begin{array}{c}9.998(2), 10.692(2) \\
13.614(3)\end{array}$ & $\begin{array}{c}15.762(3), 35.112(7), \\
7.8452(16)\end{array}$ \\
\hline$\alpha, \beta, \gamma\left({ }^{\circ}\right)$ & 90, 93.13(3), 90 & $\begin{array}{c}100.89(3), 105.05(3) \\
98.87(3)\end{array}$ & $90,90,90$ \\
\hline Volume $\left(\AA^{3}\right), Z$ & $4759.2(17), 8$ & 1348.0(5), 2 & $4341.9(15), 8$ \\
\hline$\rho_{\text {calc }}\left(\mathrm{g} \cdot \mathrm{cm}^{-3}\right)$ & 1.221 & 1.041 & 1.201 \\
\hline$\mu / \mathrm{mm}^{-1}$ & 0.7 & 0.561 & 0.624 \\
\hline $\mathrm{F}(000)$ & 1856 & 452 & 1680 \\
\hline Crystal size $\left(\mathrm{mm}^{3}\right)$ & $0.3 \times 0.2 \times 0.2$ & $0.3 \times 0.2 \times 0.2$ & $0.3 \times 0.25 \times 0.23$ \\
\hline$\theta$ range for data collection $\left(^{\circ}\right)$ & $3.136-68.242$ & $3.463-68.213$ & 3.073-62.499 \\
\hline$h, k, l$ & $-25-25,-9-9,-33-33$ & $-12-11,-12-12,-16-16$ & $-18-18,-42-42,-8-9$ \\
\hline Reflections collected & 37,917 & 24,318 & 74,888 \\
\hline Independent reflections, $R_{\text {int }}$ & $4353,0.0731$ & $4851,0.0574$ & $3455,0.0485$ \\
\hline Data/restraints/parameters & $4353 / 0 / 290$ & $4851 / 0 / 282$ & $3455 / 85 / 294$ \\
\hline Goodness-of-fit on $F^{2}$ & 1.084 & 0.996 & 1.002 \\
\hline $\mathrm{R}_{1}, w R_{2}[\mathrm{I} \geqslant \sigma(\mathrm{I})]$ & $0.0550,0.1426$ & $0.0620,0.1773$ & $0.0592,0.1474$ \\
\hline $\mathrm{R}_{1}, w R_{2}$ [all data] & $0.0717,0.1532$ & $0.0806,0.1935$ & $0.0764,0.1684$ \\
\hline Largest diff. peak/hole $\left(\mathrm{e} \cdot \AA^{-3}\right)$ & $0.30 /-0.21$ & $0.38 /-0.20$ & $0.24 /-0.18$ \\
\hline
\end{tabular}

As for crystal packing, two independent molecules form $\mathrm{R}_{2}^{2}(8)$ ring motif along the $b$ axis, see Figure 3a. Simultaneously, intermolecular hydrogen bonds $[\mathrm{C}(24)-\mathrm{H}(24) \cdots \mathrm{O}(2)$ and $\mathrm{C}(24)-\mathrm{H}(24) \cdots \mathrm{O}(4)$ ] are observed to realize a $\mathrm{R}_{2}^{1}$ (4) ring motif along the $a$ axis. The framework is further reinforced by zigzag H-bondings $[\mathrm{C}(27)-\mathrm{H}(27) \cdots \mathrm{O}(3)]$, see Figure $3 b$. The detailed intermolecular H-bonds data are presented in Table 2. 


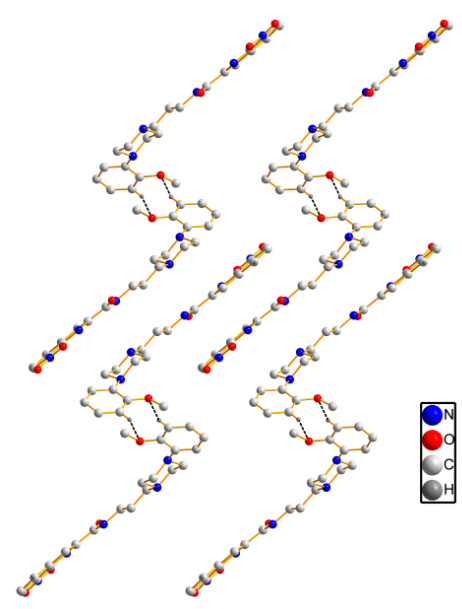

(a)

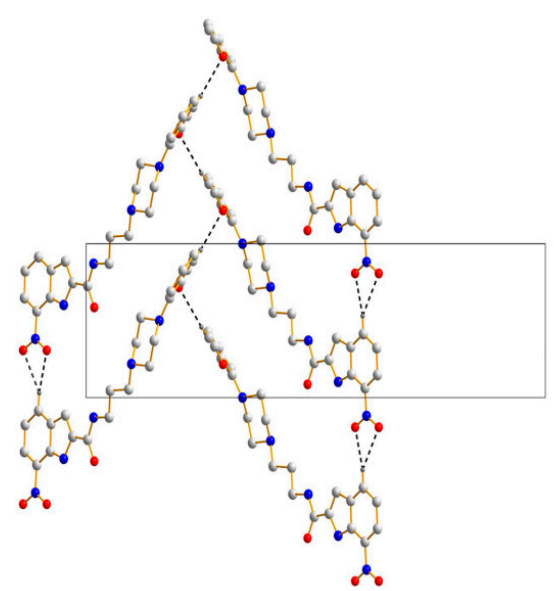

(b)

Figure 3. Crystal packing of $\mathbf{1}$. (a) viewing along the $b$ axis; (b) viewing along the $a$ axis. Black dashed lines show the intermolecular hydrogen bonds.

Table 2. Intermolecular hydrogen bonds for compound $\mathbf{1}\left(\AA,^{\circ}\right)$.

\begin{tabular}{ccccc}
\hline $\mathbf{D}-\mathbf{H} \cdots \mathbf{A}$ & $\mathbf{D}-\mathbf{H}$ & $\mathbf{H} \cdots \mathbf{A}$ & $\mathbf{D} \cdots \mathbf{A}$ & $\left.\mathbf{D}-\mathbf{H} \cdots \mathbf{A} \mathbf{(}^{\circ}\right)$ \\
\hline $\mathrm{C}(24)-\mathrm{H}(24) \cdots \mathrm{O}(2)^{\mathrm{i}}$ & 0.93 & 2.49 & $3.318(3)$ & $147.9(3)$ \\
$\mathrm{C}(24)-\mathrm{H}(24) \cdots \mathrm{O}(4){ }^{\mathrm{i}}$ & 0.93 & 2.44 & $3.294(3)$ & $152.4(2)$ \\
$\mathrm{C}(27)-\mathrm{H}(27) \cdots \mathrm{O}(3)^{\mathrm{ii}}$ & 0.93 & 2.55 & $3.409(3)$ & $154.4(3)$ \\
\hline
\end{tabular}

Symmetry code: (i) $x,-1+y, z$ (ii) $1 / 2-x,-1 / 2+y, 1 / 2-z$.

The crystal of compound 2 gives triclinic form with space group P-1, see Figure 4. The crystal data and structural refinement of compound 2 are presented in Table 1 . The dihedral angle of aromatic plane and indole ring is $11.2(9)^{\circ}$, which is obviously smaller in comparison to that of compound $\mathbf{1}$. In order to explain the discrepancy of two specific conformations, we performed conformational analysis, see Table 3. As a comparison to the bond lengths, bond angles and torsion angles between 1 and 2, significant differences are observed to be at the amide alkyl linkage, e.g., the torsion angle $[\mathrm{N}(2)-\mathrm{C}(20)-\mathrm{C}(8)-\mathrm{C}(19)]$ of $\mathbf{1}$ is $-179.0(2)^{\circ}$ while corresponding angle [N(2)-C(12)-C(13)-C(14)] of 2 is $-52.6(3)^{\circ}$. This case is most likely ascribed to the differences of intramolecular and intermolecular hydrogen bonds that promote the formation of specific conformers.

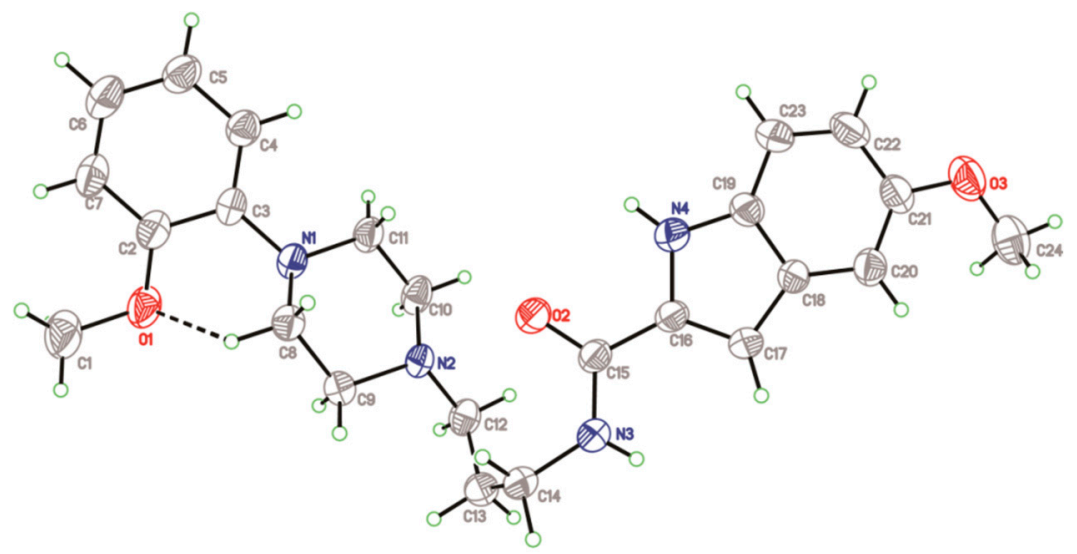

Figure 4. Crystallographic structure of compound 2. Displacement ellipsoids are drawn at the $30 \%$ probability level, and intramolecular hydrogen bond is shown in dashed line. 
Table 3. Selected geometric parameters of compound 1 and $2\left(\AA,^{\circ}\right)$.

\begin{tabular}{cccc}
\hline Compound 1 & \multicolumn{2}{c}{ Compound 2 } \\
\hline Bonds & Dist. & Bonds & Dist. \\
$\mathrm{N}(1)-\mathrm{C}(17)$ & $1.419(2)$ & $\mathrm{N}(1)-\mathrm{C}(3)$ & $1.413(3)$ \\
$\mathrm{N}(1)-\mathrm{C}(10)$ & $1.464(2)$ & $\mathrm{N}(1)-\mathrm{C}(8)$ & $1.474(3)$ \\
$\mathrm{N}(3)-\mathrm{C}(14)$ & $1.337(2)$ & $\mathrm{N}(3)-\mathrm{C}(15)$ & $1.331(3)$ \\
$\mathrm{N}(4)-\mathrm{C}(11)$ & $1.393(2)$ & $\mathrm{N}(4)-\mathrm{C}(16)$ & $1.370(3)$ \\
$\mathrm{C}(8)-\mathrm{C}(20)$ & $1.512(3)$ & $\mathrm{C}(12)-\mathrm{C}(13)$ & $1.504(4)$ \\
Angle & $\left({ }^{\circ}\right.$ & Angle & $\left({ }^{\circ}\right)$ \\
$\mathrm{C}(20)-\mathrm{C}(8)-\mathrm{C}(19)$ & $110.64(17)$ & $\mathrm{C}(12)-\mathrm{C}(15)-\mathrm{C}(14)$ & $115.9(2)$ \\
$\mathrm{C}(19)-\mathrm{N}(3)-\mathrm{C}(14)$ & $122.09(18)$ & $\mathrm{C}(15)-\mathrm{N}(3)-\mathrm{C}(14)$ & $121.7(2)$ \\
$\mathrm{N}(2)-\mathrm{C}(20)-\mathrm{C}(8)-\mathrm{C}(19)$ & $-179.0(2)$ & $\mathrm{N}(2)-\mathrm{C}(12)-\mathrm{C}(13)-\mathrm{C}(14)$ & $-52.6(3)$ \\
$\mathrm{C}(20)-\mathrm{C}(8)-\mathrm{C}(19)-\mathrm{N}(3)$ & $171.5(2)$ & $\mathrm{C}(12)-\mathrm{C}(13)-\mathrm{C}(14)-\mathrm{N}(3)$ & $-56.2(3)$ \\
$\mathrm{C}(8)-\mathrm{C}(19)-\mathrm{N}(3)-\mathrm{C}(14)$ & $171.2(2)$ & $\mathrm{C}(13)-\mathrm{C}(14)-\mathrm{N}(3)-\mathrm{C}(15)$ & $94.9(3)$ \\
\hline
\end{tabular}

Another particular interest for us in studying the crystal structure of $\mathbf{2}$ is to investigate the stability force comprising intermolecular interactions. As shown in Figure 5, $\mathrm{C}-\mathrm{H} \cdots \pi$ interactions are found to be the critical forces to stabilize the three-dimensional structure [21]. The geometry parameters of $\mathrm{C}-\mathrm{H} \cdots \pi$ interactions are listed in Table 4. Two molecules form a dimer of head-tail crosslinking through $\mathrm{C}(24)-\mathrm{H}(24 \mathrm{~B}) \cdots \pi$ interactions. Additionally, a dimer constructed by two antiparallel molecules plays a significant role in stabilizing the packing structure.

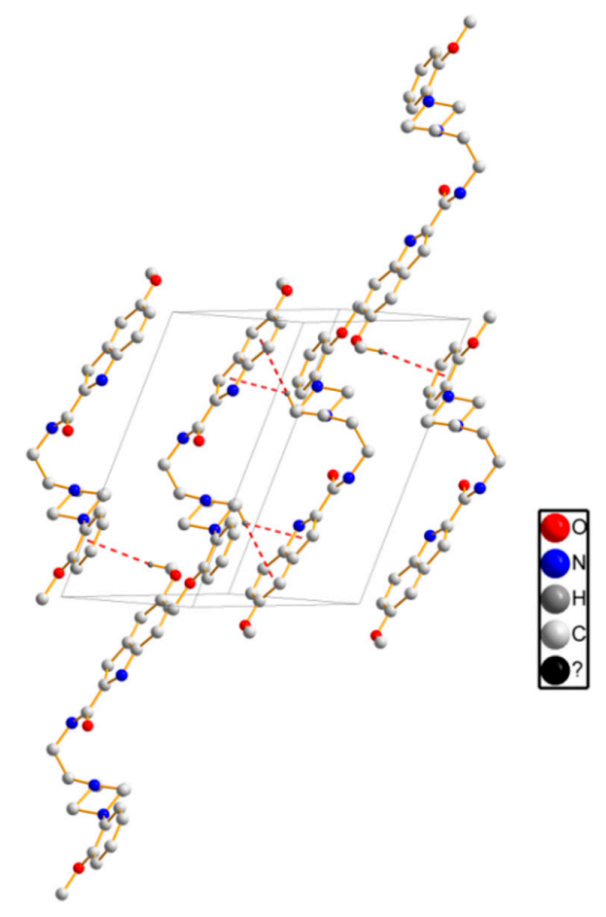

Figure 5. Crystal packing of 2. Red dashed lines show the intermolecular $\mathrm{C}-\mathrm{H} \cdots \pi$ interactions.

Table 4. $\mathrm{C}-\mathrm{H} \cdots \pi$ interaction geometry of compound $2\left(\AA{ }^{\circ}\right)$.

\begin{tabular}{clccc}
\hline$\cdots \mathbf{X}-\mathbf{H}$ & \multicolumn{1}{c}{$\mathbf{C g}{ }^{*}$} & $\mathbf{H} \cdots \mathbf{C g}$ & $\mathbf{X} \cdots \mathbf{C g}$ & $\mathbf{X}-\mathbf{H} \cdots \mathbf{C g}\left({ }^{\circ}\right)$ \\
\hline $\mathrm{C}(10)-\mathrm{H}(10 \mathrm{~A})^{\mathrm{i}}$ & $\mathrm{N}(4)-\mathrm{C}(16)-\mathrm{C}(17)-\mathrm{C}(18)-\mathrm{C}(19)$ & 2.70 & $3.437(3)$ & 133 \\
$\mathrm{C}(10)-\mathrm{H}(10 \mathrm{~A})^{\mathrm{i}}$ & $\mathrm{C}(18)-\mathrm{C}(19)-\mathrm{C}(23)-\mathrm{C}(22)-\mathrm{C}(21)-\mathrm{C}(20)$ & 2.78 & $3.753(3)$ & 178 \\
$\mathrm{C}(24)-\mathrm{H}(24 \mathrm{~B})^{\mathrm{ii}}$ & $\mathrm{C}(2)-\mathrm{C}(3)-\mathrm{C}(4)-\mathrm{C}(5)-\mathrm{C}(6)-\mathrm{C}(7)$ & 3.00 & $3.917(4)$ & 160 \\
\hline
\end{tabular}

Symmetry code: (i) $1-x, 1-y, 1-z$; (ii) $x, 1+y, 1+z$. The centroids of the planar rings are presented by asterisk $(*)$. 
Crystal structure of compound 3 was herein described clearly. It gives orthorhombic with space group Pccn. As shown in Figure 6, the piperazine ring, $\mathrm{C}(12)$ and $\mathrm{C}(13)$ atoms were disordered. The dihedral angle of aromatic plane and indole ring is $57.6(8)^{\circ}$. With respect to the packing structure, the intermolecular hydrogen bonds (Table 5) form network structure. The $\mathrm{NH}[\mathrm{N}(3)-\mathrm{H}(3)$, $\mathrm{N}(4)-\mathrm{H}(4)$ ] of a donor molecule realizes $\mathrm{H}$-bond with the $\mathrm{O}$ atoms of an adjacent molecule, see Figure 7. Furthermore, compared to hydrogen bonds (3.294-3.409 $\AA$ ) in compound 1, the H-bonds (2.953-3.151 $\AA$ ) in compound 3 have shorter bond lengths, indicating that higher bond energies contribute to the stability of the three-dimensional structure of 3 .

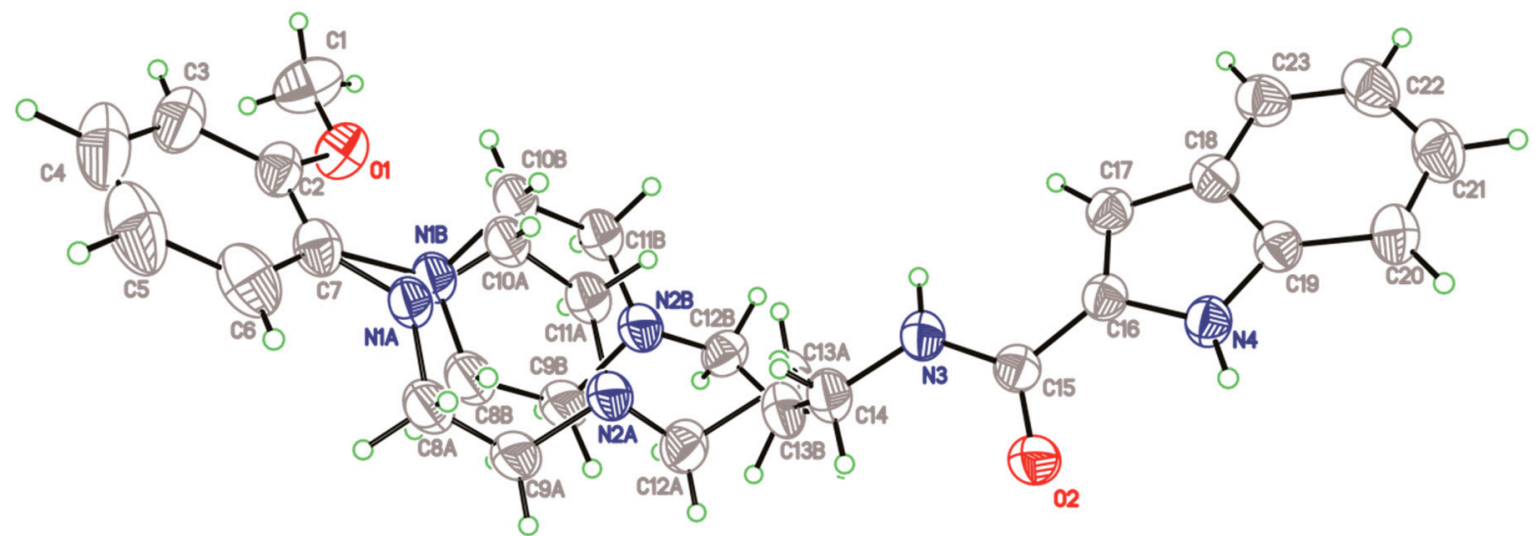

Figure 6. Crystallographic structure of compound 3. Displacement ellipsoids are drawn at the $30 \%$ probability level.

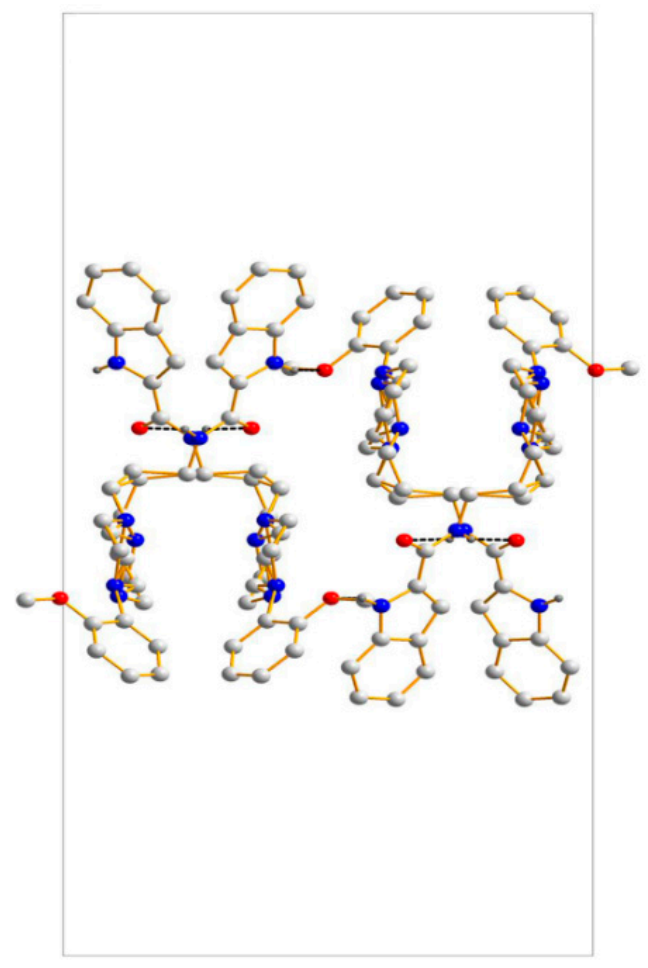

Figure 7. Crystal packing of 3 along the $c$ axis. Black dashed lines show the intermolecular H-bonds. 
Table 5. Intermolecular hydrogen bonds for compound $3\left(\AA,^{\circ}\right)$.

\begin{tabular}{|c|c|c|c|c|}
\hline $\mathbf{D}-\mathbf{H} \cdots \mathbf{A}$ & D-H & $\mathbf{H} \cdots \mathbf{A}$ & $\mathbf{D} \cdots \mathbf{A}$ & D-H $\cdots$ A $\left(^{\circ}\right)$ \\
\hline $\mathrm{N}(3)-\mathrm{H}(3) \cdots \mathrm{O}(2)^{\mathrm{i}}$ & 0.86 & 2.14 & $2.953(4)$ & $157.5(2)$ \\
\hline $\mathrm{N}(4)-\mathrm{H}(4) \cdots \mathrm{O}(1){ }^{\mathrm{ii}}$ & 0.86 & 2.37 & $3.151(1)$ & $151.7(2)$ \\
\hline
\end{tabular}

\subsection{DFT Calculations}

Compounds 1-3 were subject to theoretical calculations using Gaussian 09 at the B3LYP/6-311G $(\mathrm{d}, \mathrm{p})$ level of theory to elucidate their structural properties. The optimized geometries are shown in Figure 8. The comparison of the calculated bond lengths and bond angles among compounds 1-3 and the corresponding solid-state values are listed in Table 6 . The bond-length deviations between the calculated and solid-state conformers are 0.001 to $0.021 \AA$, and the deviations of bond angles range from 0.1 to $1.6^{\circ}$. The results suggest that there is no apparent difference between the theoretically calculated and experimental crystallographic conformations.

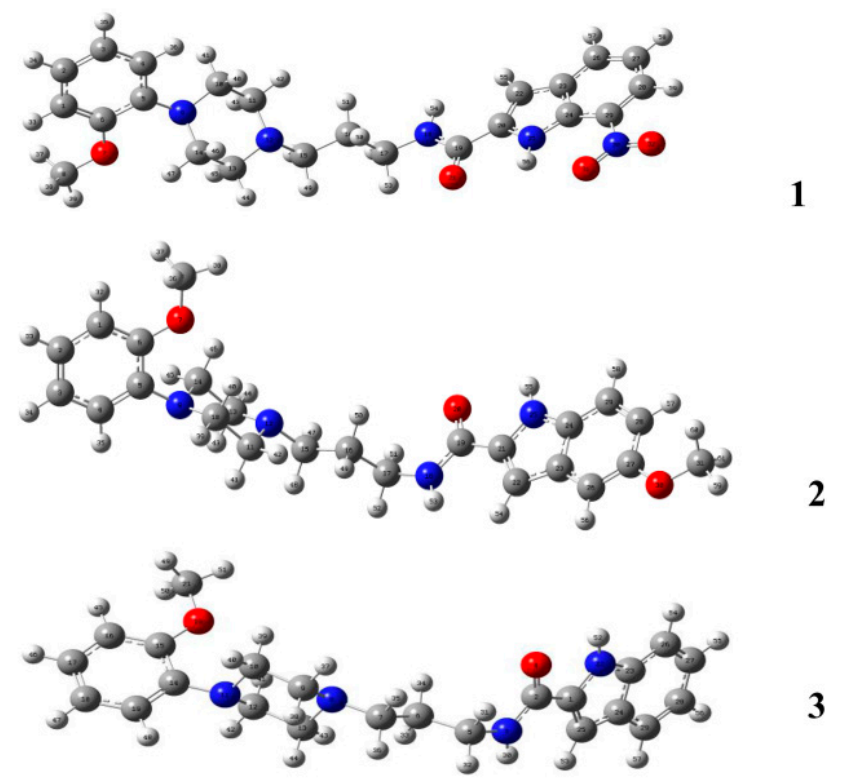

Figure 8. DFT-optimized conformations of compound 1, 2 and 3 at the B3LYP/6-311G (d, p) level of theory.

Table 6. Optimized geometrical parameters of theoretically calculated and solid-state conformers.

\begin{tabular}{ccc}
\hline & Compound 1 & \\
\hline Bond lengths $(\AA)$ & DFT & X-ray \\
$\mathrm{O}(7)-\mathrm{C}(6)$ & 1.362 & $1.373(3)$ \\
$\mathrm{N}(25)-\mathrm{C}(24)$ & 1.354 & $1.362(2)$ \\
$\mathrm{C}(15)-\mathrm{C}(16)$ & 1.525 & $1.511(3)$ \\
$\mathrm{C}(27)-\mathrm{C}(28)$ & 1.396 & $1.385(3)$ \\
Bond angles $\left(^{\circ}\right)$ & & \\
$\mathrm{C}(20)-\mathrm{C}(19)-\mathrm{N}(18)$ & 116.5 & $115.8(2)$ \\
$\mathrm{C}(15)-\mathrm{C}(16)-\mathrm{C}(17)$ & 111.5 & $110.8(2)$ \\
$\mathrm{N}(12)-\mathrm{C}(15)-\mathrm{C}(16)$ & 113.3 & $114.9(2)$ \\
\hline
\end{tabular}


Table 6. Cont.

\begin{tabular}{ccc}
\hline & Compound 2 & \\
\hline Bond lengths $(\AA)$ & DFT & X-ray \\
$\mathrm{O}(7)-\mathrm{C}(6)$ & 1.36 & $1.380(3)$ \\
$\mathrm{N}(25)-\mathrm{C}(24)$ & 1.371 & $1.370(3)$ \\
$\mathrm{C}(15)-\mathrm{C}(16)$ & 1.527 & $1.515(4)$ \\
$\mathrm{C}(27)-\mathrm{C}(28)$ & 1.409 & $1.394(4)$ \\
Bond angles $\left(^{\circ}\right)$ & & \\
$\mathrm{O}(21)-\mathrm{C}(19)-\mathrm{C}(18)$ & 123.4 & $122.6(2)$ \\
$\mathrm{C}(15)-\mathrm{C}(16)-\mathrm{C}(17)$ & 111.5 & $115.9(2)$ \\
$\mathrm{N}(12)-\mathrm{C}(15)-\mathrm{C}(16)$ & 113.5 & $114.5(2)$ \\
\hline & Compound 3 & \\
\hline Bond lengths $(\AA)$ & $\mathrm{DFT}$ & $\mathrm{X}-\mathrm{ray}$ \\
$\mathrm{O}(4)-\mathrm{C}(2)$ & 1.221 & $1.242(3)$ \\
$\mathrm{N}(22)-\mathrm{C}(23)$ & 1.366 & $1.506(9)$ \\
$\mathrm{C}(5)-\mathrm{C}(7)$ & 1.524 & $1.376(4)$ \\
$\mathrm{C}(14)-\mathrm{C}(19)$ & 1.385 & $122.3(2)$ \\
Bond angles $\left({ }^{\circ}\right)$ & & $115.0(2)$ \\
$\mathrm{O}(4)-\mathrm{C}(2)-\mathrm{N}(3)$ & 123.4 & $107.5(2)$ \\
$\mathrm{O}(20)-\mathrm{C}(15)-\mathrm{C}(14)$ & 116.0 & \\
$\mathrm{~N}(22)-\mathrm{C}(23)-\mathrm{C}(24)$ & 107.4 & \\
\hline
\end{tabular}

Molecular orbitals are very useful for physicists and chemists because the energy gap between HOMO and LUMO characterizes the chemical reactivity and kinetic stability of molecule [22]. As shown in Figure 9, the HOMO of $\mathbf{1}$ is localized on the arylpiperazine moiety, whereas the LUMO is mainly concentrated on the 7-nitro- $1 \mathrm{H}$-indole moiety. The HOMO and LUMO orbitals of $\mathbf{2}$ and $\mathbf{3}$ are localizes over the amide and indole moieties. The HOMO-LUMO energy gaps are 2.728, 4.324 and $4.610 \mathrm{eV}$ for compound $\mathbf{1}, \mathbf{2}$ and $\mathbf{3}$, respectively (Table 7).

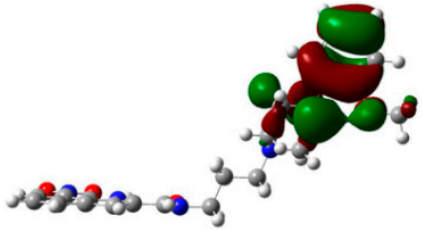

1-HOMO

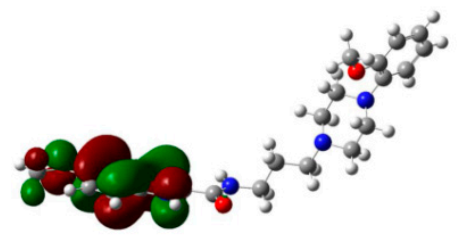

2-HOMO

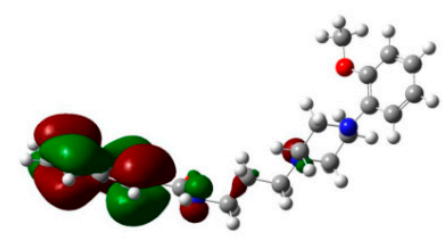

3-HOMO

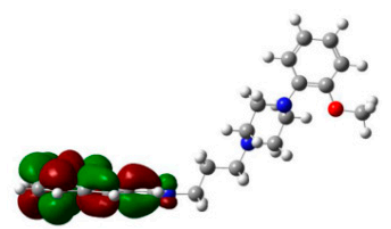

1-LUMO
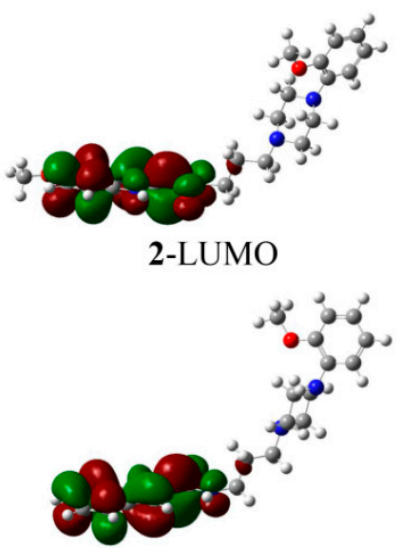

3-LUMO

Figure 9. HOMO, LUMO surfaces of compound 1, 2 and 3 simulated at the B3LYP/6-311G (d, p) level of theory. 
Table 7. Frontier molecular orbital energies of 1, 2 and $3(\mathrm{eV})$.

\begin{tabular}{cccc}
\hline Compound & $E_{\text {HOMO }}$ & $E_{\text {LUMO }}$ & $\Delta E_{\text {LUMO-HOMO }}$ \\
\hline $\mathbf{1}$ & -5.395 & -2.667 & 2.728 \\
$\mathbf{2}$ & -5.508 & -1.184 & 4.324 \\
$\mathbf{3}$ & -5.807 & -1.197 & 4.610 \\
\hline
\end{tabular}

Chemical hardness is a useful concept for understanding the behavior of chemical systems and is associated with the stability and reactivity of a chemical system. The chemical hardness $(\eta)$ can be expressed as: $\eta=\left(-E_{\mathrm{HOMO}}+E_{\mathrm{LUMO}}\right) / 2$. Using HOMO and LUMO orbital energies, we determined that the values of $\eta_{1}, \eta_{2}$ and $\eta_{3}$ are 1.364, 2.162 and $2.305 \mathrm{eV}$, respectively. The results suggest that $\mathbf{1}$ is more reactive and less stable than $\mathbf{2}$ and 3 . Electronic chemical potential $(\mu)$ is defined as the escaping tendency of electrons from an equilibrium system and is given by $\mu=\left(E_{\mathrm{HOMO}}+E_{\mathrm{LUMO}}\right) / 2$. The $\mu$ values increase in the order of $\mathbf{1}(-4.031 \mathrm{eV})<\mathbf{3}(-3.502 \mathrm{eV})<\mathbf{2}(-3.346 \mathrm{eV})$. Generally, hard molecules will have their electron density changed more hardly than a soft molecule [23]. In this case, the chemical hardness of $\mathbf{3}$ is larger than that of $\mathbf{2}$, but the electronic chemical potential of the former is slightly smaller than the latter. It may be ascribed to the intermolecular hydrogen bonds of 3 that facilitate the electronic transfers. The global electrophilicity power of a ligand, expressed as $\omega=\mu^{2} / 2 \eta$, is a measure of the stabilization in energy achieved when the system acquires an additional electronic charge from the environment. The corresponding $\omega$ values of 1,2 and 3 are $5.956,2.589$ and 2.660 , respectively.

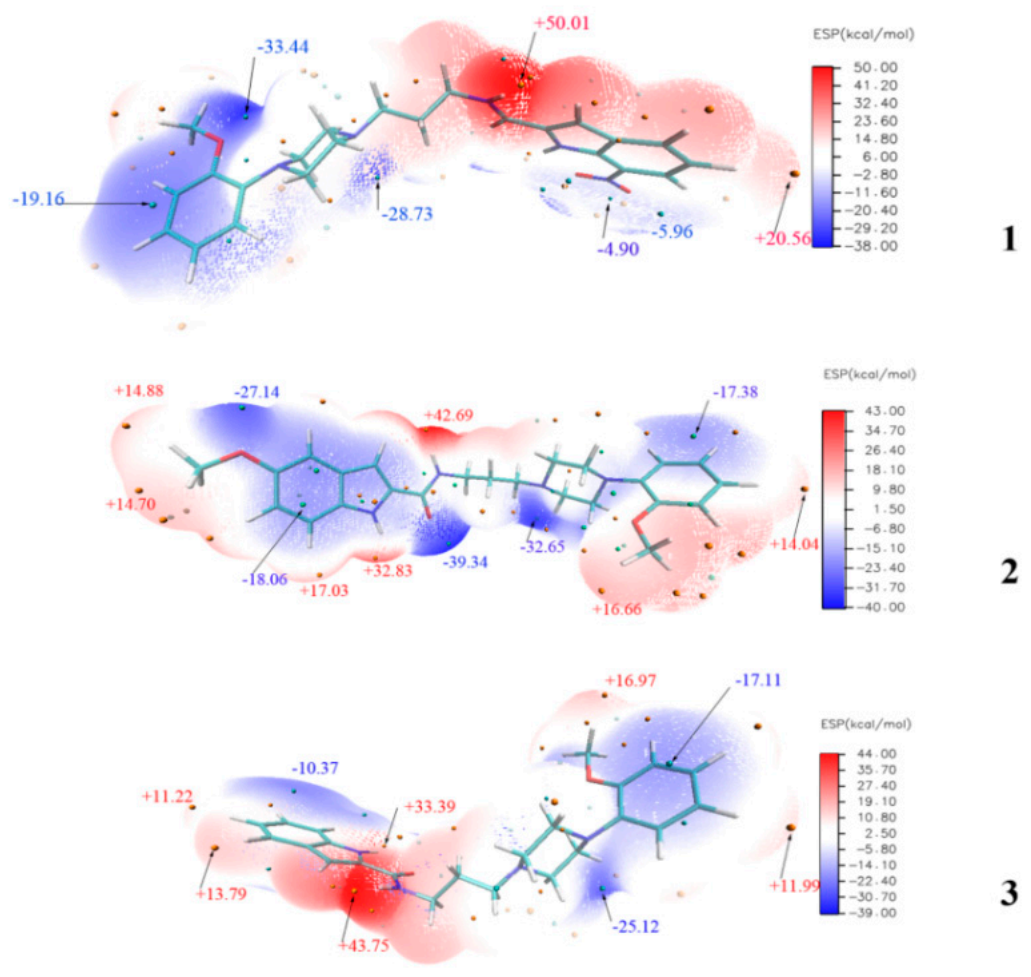

Figure 10. MEP surfaces of compound 1, 2 and 3.

The molecular electrostatic potential (MEP) maps were evaluated using the B3LYP method with the basis set of 6-311G $(\mathrm{d}, \mathrm{p})$ to investigate the reactive sites of electrophilic and nucleophilic attacks for the title compounds. The positive (red) regions of MEP were related to nucleophilic reactivity, and the negative (blue) regions referred to electrophilic reactivity. Determining electrostatic potential is a suitable process for analysis based on "recognition" of one molecule by another, similar to that in 
drug receptor and enzyme substrate interactions, because the two species detect each other through their potentials [24,25]. As shown by the MEP map of 1 (Figure 10), the negative regions are mainly localized over the anisole ring. The maximum positive region is over the $\mathrm{NH}$ portion of the amide group $(+50.01 \mathrm{kcal} / \mathrm{mol})$. Similar to that of compound 1, the maximum positive region of 2 is localized to its own $\mathrm{NH}$ group $(+42.69 \mathrm{kcal} / \mathrm{mol})$, and the maximum negative site is concentrated on the $\mathrm{O}$ atom of the amide group $(-39.34 \mathrm{kcal} / \mathrm{mol})$. The $\mathrm{N}$ atom in the piperazine ring $(-32.65 \mathrm{kcal} / \mathrm{mol})$ also displays significant electrophilic reactivity. Nevertheless, the $\mathrm{NH}$ of indole ring exhibits a strong nucleophilic reactivity $(+32.83 \mathrm{kcal} / \mathrm{mol})$. These findings suggest that the above-mentioned sites are involved in the hydrogen-bonding interactions, which is validated by molecular model of the 2- $\alpha_{1 \mathrm{~A}}$ complex (Figure 11b). The maximum positive region for 3 is also localized to the NH group $(+43.75 \mathrm{kcal} / \mathrm{mol})$.

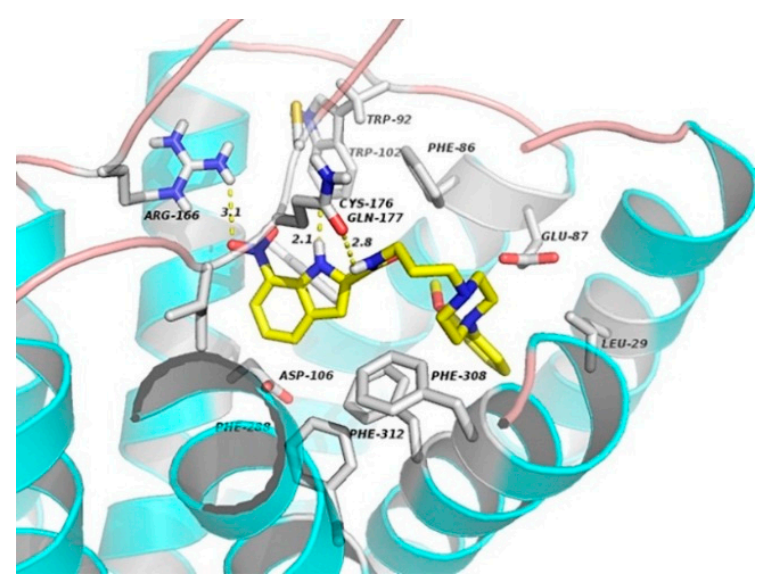

(a)

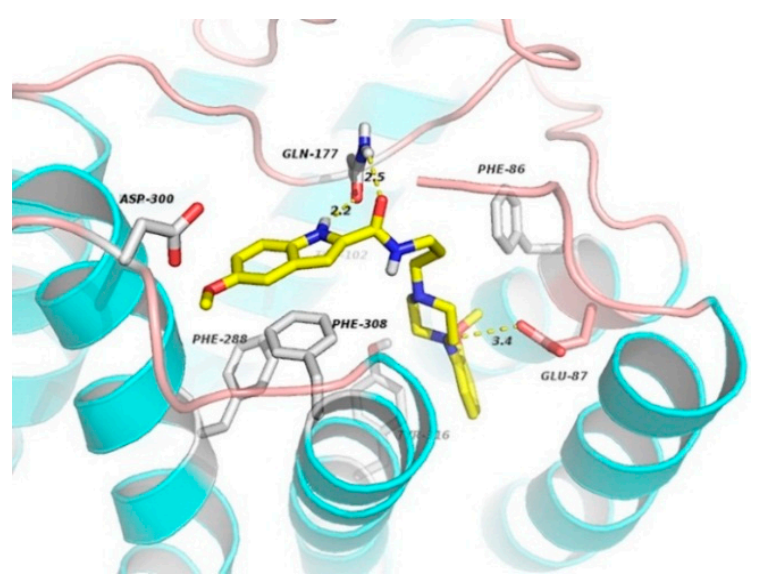

(b)

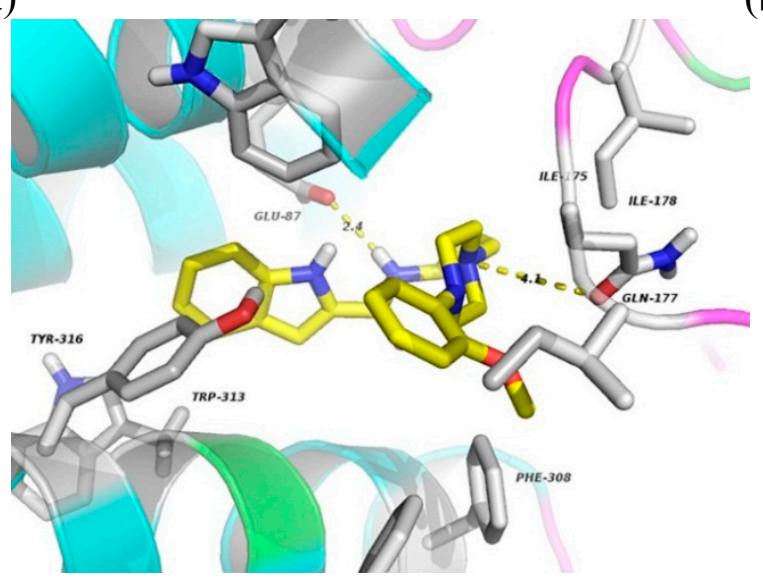

(c)

Figure 11. The docking complexes of ligands 1 (a); 2 (b); and 3 (c) with $\alpha_{1 \mathrm{~A}}$-AR. These compounds are shown in stick representation. The elements are coloured as follows: oxygen, red; nitrogen, blue; carbon, yellow. Dashed lines represent the hydrogen bonds or electrostatic interactions.

\subsection{Binding Mechanisms of the Ligand- $\alpha_{1 A}$ Complex}

G protein-coupled receptors (GPCRs) are the largest class of membrane receptors in eukaryotes, and are characterized by seven transmembrane (TM) helices, and $\mathrm{N}$ - and C-terminal fragments. The TM helices are connected by alternating intra- and extracellular loop (ECL) regions that are very flexible and important for a wide range of biological functions. When agonists or antagonists bind to GPCRs, the hosts act as molecular switches that modulate downstream effector proteins when turned on [26]. $\alpha_{1 \mathrm{~A}}$-Adrenoceptor is a member of the GPCR family. The accurate crystal structure of $\alpha_{1 \mathrm{~A}}$ at 
the atomic resolution cannot be obtained, thereby severely impeding the development of therapeutic BPH medicines through structure-based drug design. Nevertheless, homology-modeling procedures with continuous progresses provide viable tools for structure-based GPCR ligand design.

Functional experiments involving animal tissues validated that compound 1, 2 and 3 exhibit 11.0-, 18.6- and 4.7-fold increases in selectivity, respectively, for $\alpha_{1 \mathrm{~A}}$ over than the $\alpha_{1 \mathrm{~B}}$ subtype [13]. The minimum-energy structures of the ligands were subject to molecular docking using a homology model of the $\alpha_{1 \mathrm{~A}}$ receptor to determine the structure-activity-binding mechanism relationship. As shown in Figure 10a, NH in the indole ring as a donor forms H-bond (2.1 $\AA$ ) with Cys176 residue. The NH of amino group realizes a hydrogen bond $(2.8 \AA)$ with the carbonyl oxygen atom of Gln177 in the ECL2 region that has been proved to be essential for GPCR activation [27]. The indole and benzene rings mainly engage in hydrophobic interactions with Trp102, Trp92, Phe86, Phe308, Phe288 and Phe312. The residues including Asp106, Glu87 and Leu29 participate in 1 binding to the $\alpha_{1 \mathrm{~A}}$ receptor with van der Waals interactions. In the 2- $\alpha_{1 \mathrm{~A}}$-adrenoceptor complex, the $\mathrm{NH}$ in indole ring and the carbonyl oxygen atom are involved in two hydrogen bonds with the nitrogen and oxygen atoms of Gln177 (2.2 and $2.5 \AA$ ). In addition, 2 contacts via hydrophobic interactions with residues Phe86, Tyr316 and Phe288. The indole ring forms aromatic $\pi$-stacking against Phe308 of TM7 (Figure 10b). The cationic nitrogen atom in the piperazine ring for the electrostatic binding to Glu87 of TM2 is also presented. As observed from 3- $\alpha_{1 \mathrm{~A}}$ complex (Figure 10c), the $\mathrm{NH}$ of amino group can realize a H-bond (2.4 $\AA$ ) with Glu87 of ECL1. The indole and benzene rings for hydrophobic interactions with the region formed by Tyr316, Trp313, Phe308 of TM7 and Phe288 of TM6 are found. The arylpiperazine moiety is in weak van der waals contact with residues Ile175 and Ile178 of ECL2. The protonated piperazine moiety forms a weak electrostatic interaction with Gln177 (4.1 Å between the nitrogen atom of piperazine ring and the amide oxygen atom of Gln177).

To shed some light on the selectivity for $\alpha_{1 \mathrm{~A}}$ over than $\alpha_{1 \mathrm{~B}}$ subtype, molecular dockings using a homology of $\alpha_{1 B}$ receptor were performed. The results show that the oxygen atom of nitrate group of 1 forms two hydrogen bonds with residues Ser207 and Ser211 (3.1 and 2.9 A) of TM5. The indole and benzene rings mainly engage in hydrophobic interactions with Phe310, Phe311, Phe334 and Trp121 residues (Figure 12a). As for $2-\alpha_{1 \mathrm{~B}}$ complex, the ligand contacts via hydrophobic interactions with Phe330, Phe334 and Tyr203. Other residues, including Leu134 and Lys185, involve in ligand binding by van der Waal's forces. Additionally, the cationic nitrogen atom in the piperazine moiety for electrostatic binding to Asp125 (3.1 $\AA$ ) is also observed as shown in Figure 11b. One residue Phe334 in TM7 may be an important binding site for 3- $\alpha_{1 \mathrm{~A}}$ complex by $\pi$-stacking interaction. Compound 3 contacts via van der Waals interactions with residues Ser102, Glu194, Val197 and Leu134. The indole moiety involves in hydrophobic interactions with Phe330 and Trp307. In addition, the electronegative atom oxygen in Asp125 of TM3 makes an electrostatic interaction with the nitrogen atom of the piperazine ring.

Studies on the binding mechanism indicate that residues Gln177, Phe86, Phe308, Phe288 and Glu87 are identified as the major sites for indole-arylpiperazine derivatives (1, 2 and $\mathbf{3})$ binding to $\alpha_{1 \mathrm{~A}}$ receptor. On the other hand, the important sites for ligands binding with $\alpha_{1 \mathrm{~B}}$ subtype are involved in Asp125, Leu134, Phe334, Phe330, Ser207 and Ser211 residues. We also noticed that the Gln177 residue in ECL2 seems to play a significant role in improving the selectivity of $\alpha_{1 \mathrm{~A}}$ against $\alpha_{1 \mathrm{~B}}$ subtype. The ligands binding to residue Asp125 by electrostatic interactions and contacting Phe334 via hydrophobic interactions or $\pi$-stacking interactions contribute to increased affinity for $\alpha_{1 \mathrm{~B}}$ receptor. 

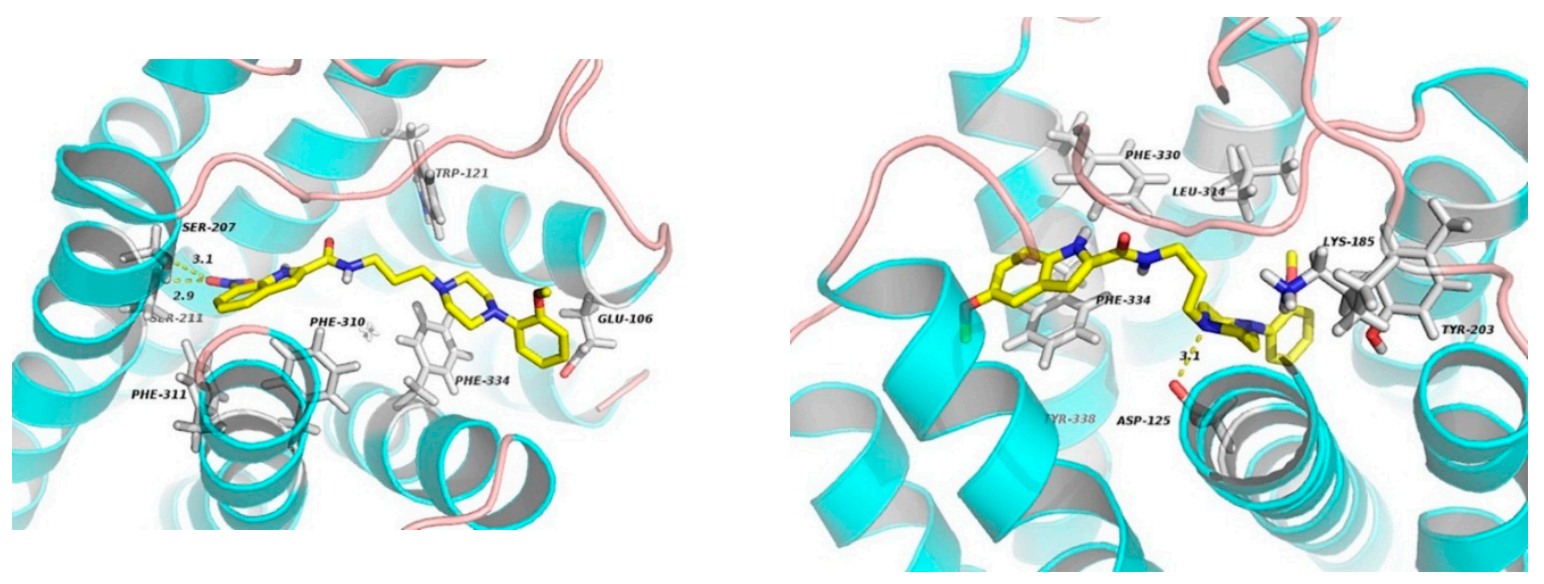

(a)

(b)

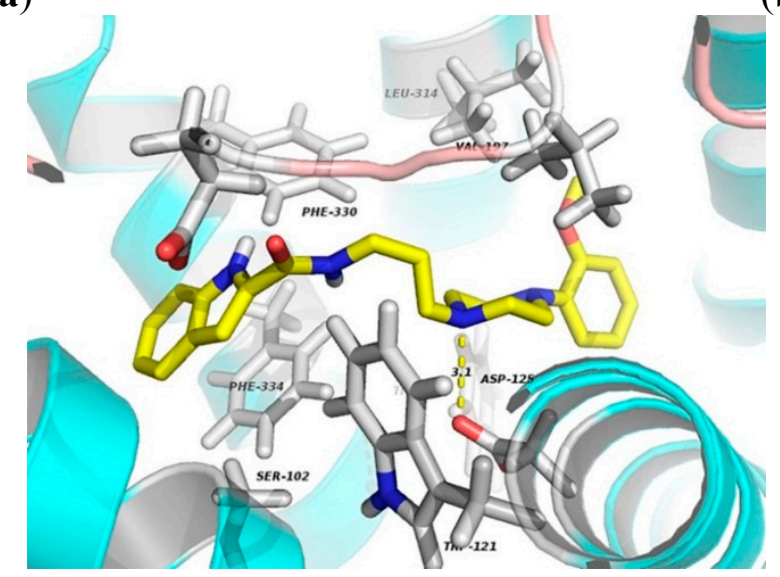

(c)

Figure 12. The docking complexes of ligands 1 (a); 2 (b); and 3 (c) with $\alpha_{1 \mathrm{~B}}-\mathrm{AR}$. These compounds are shown in stick representation. The elements are coloured as follows: oxygen, red; nitrogen, blue; carbon, yellow. Dashed lines represent the hydrogen bonds or electrostatic interactions.

\section{Experimental Section}

\subsection{Chemical Synthesis}

The title compound 1, 2 and $\mathbf{3}$ were synthesized by our previous work [13], and characterized by ${ }^{1} \mathrm{H}-$ and ${ }^{13} \mathrm{C}-\mathrm{NMR}$.

\subsection{X-ray Crystallography}

Suitable crystals of compound 1-3 were obtained by slowly evaporating a mixture of dichloromethane and $n$-hexane solution at ambient temperature, and single crystal of compound 2 was obtained from a solution of tetrahydrofuran and n-pentane. High-quality colorless crystals were mounted on a glass fiber in a random orientation. The data were collected by a R-AXIS RAPID II diffractometer (Rigaku Co., Ltd., Matsubaracho Akishima, Japan) equipped with graphite-monochromatic $\mathrm{Cu}-K \alpha$ radiation $(\lambda=1.54178 \AA)$ by using a $\omega$ scan mode. The structures were solved by direct methods using Olex 2 software [26], and the non-hydrogen atoms were located from the trial structure and then refined anisotropically with SHELXL using a full-matrix least squares procedure based on $F^{2}$ [28]. The weighted $R$ factor, $w R$ and goodness-of-fit $S$ values were obtained based on $F^{2}$. The hydrogen atom positions were fixed geometrically at the calculated distances and allowed to ride on the parent atoms. CCDC 1007945 (1), 1009714 (2), and 1021886 (3) contain the supplementary crystallographic data for this paper. These data can be obtained free of charge via 
http://www.ccdc.cam.ac.uk/conts/retrieving.html (or from the CCDC, 12 Union Road, Cambridge CB2 1EZ, UK; Fax: +44 1223 336033; E-mail: deposit@ccdc.cam.ac.uk.

\subsection{Theoretical Calculations}

The initial conformational optimizations were performed at the molecular mechanics level of theory employing MM+ force fields incorporated in HyperChem 7.5 software package [29]. The conformer further submitted to the Gaussian 09 for DFT optimization at the B3LYP/6-311G (d, p) level of theory. Harmonic vibration frequencies were calculated to confirm the stability of these conformers [30]. As revealed by the frequency analysis, no imaginary frequencies were observed in ground states. Molecular orbitals were plotted by using GaussView (version 5.0.8, Gaussian Inc., Wallingford, CT, USA). MEP maps were constructed by the Multiwfn program [31].

\subsection{Homology Modeling and Molecular Docking}

The amino acidic sequence of the human $\alpha_{1 \mathrm{~A}}$ receptor was retrieved from SwissProt database (entry code P35348, A1AA_HUMAN) [32]. Based on Zhou's work [33], the 3D model of $\alpha_{1 \mathrm{~A}}$ was perfectly achieved with a TM-score of 0.65 . Generally, models with TM-score $>0.4$ have significant similarity to native structures. The model was then submitted to be energy optimization by using CHARMMing program [34]. The loop conformations of energy-optimized model were reasonably modified by the Scwrl4 software [35], which produced the final homology model of $\alpha_{1 \mathrm{~A}}$ receptor. Stable conformations of $\mathbf{1}, \mathbf{2}$ and $\mathbf{3}$ that were extracted from the single-crystal structures were saved in PDB format. Autodock vina was employed to perform the molecular docking [36,37], and the preferential binding mode was finally selected according to the lowest affinity energy $(\mathrm{kcal} / \mathrm{mol})$. Afterward, the full color was obtained by using the program PyMOL. The human $\alpha_{1 \mathrm{~B}}$ model was obtained according to the reported literature [38].

\section{Conclusions}

Numerous indole-arylpiperazine derivatives exhibit considerable selectivity for $\alpha_{1}$-AR subtype, but the structure-activity-binding mechanism relationship remains unclear. In the present work, compounds 1, 2 and 3 were investigated using single-crystal X-ray diffraction analysis, theoretical calculations and molecular docking based on the homology models of $\alpha_{1 \mathrm{~A}}$ and $\alpha_{1 \mathrm{~B}}$ receptors. Crystals of 1,2 and 3 belong to the monoclinic form with $C 2 / c$ space group, triclinic form with space group $P-1$ and orthorhombic with space group Pccn, respectively. Intra- and intermolecular hydrogen bonds play a significant role in the packing structures of $\mathbf{1}$. For compound $2, \mathrm{C}-\mathrm{H} \cdots \pi$ interactions are critical forces to stabilize the three-dimensional structure. The intermolecular H-bonds of $\mathbf{3}$ form a network structure, and have higher bonds energies by comparison to that of $\mathbf{1}$. The HOMO-LUMO energy gaps were obtained by DFT calculations at B3LYP/6-311G $(\mathrm{d}, \mathrm{p})$ level of theory. The results suggest that compound $\mathbf{1}$ is less kinetically stable than compound $\mathbf{2}$ and $\mathbf{3}$. MEP maps of these compounds indicate that the positive regions are mainly localized over the $\mathrm{NH}$ group, and the regions of electrophilic reactivity are distributed in the $\mathrm{C}=\mathrm{O}$ group and $\mathrm{N}$ atom in the piperazine ring. Molecular docking of ligand- $\alpha_{1}$-receptor complex was performed to illustrate the structure-activity-binding mechanism relationship. Residues Gln177, Phe86, Phe308, Phe288 and Glu87 are identified as the major sites for ligands binding to $\alpha_{1 \mathrm{~A}}$ receptor while the important sites for ligands binding with $\alpha_{1 \mathrm{~B}}$ subtype are involved in Asp125, Leu134, Phe334, Phe330, Ser207 and Ser211 residues. The present work provides valuable clues for designing $\alpha_{1 \mathrm{~A}}$-selective antagonists with better efficacy.

Supplementary Materials: Supplementary materials can be accessed at: http://www.mdpi.com/1420-3049/ 20/11/19651/s1.

Acknowledgments: This work was supported by grants from the Technological Innovation Project of Colleges and Universities in Guangdong Province (No. cx2d1127), the National Science Foundation of Guangdong Province (No. S2013040014088). 
Author Contributions: W.X., R.-W.J. and M.Y. planed the study and wrote the paper. J.-J.H., B.-H.S. and X.-J.X. synthesized the compounds, cultured the single crystals and obtained the crystallographic data. W.X. performed the molecular docking. All authors have given approval to the final version of the manuscript.

Conflicts of Interest: The authors declare no conflict of interest.

\section{References}

1. Sarswat, A.; Kumar, R.; Kumar, L.; Lal, N.; Sharma, S.; Prabhakar, Y.S.; Pandey, S.K.; Lal, J.; Verma, V.; Jain, A.; et al. Arylpiperazines for management of benign prostatic hyperplasia: Design, synthesis, quantitative structure-activity relationships, and pharmacokinetic studies. J. Med. Chem. 2011, 54, 302-311. [CrossRef] [PubMed]

2. Meyer, M.D.; Altenbach, R.J.; Basha, F.Z.; Carroll, W.A.; Condon, S.; Elmore, S.W.; Kerwin, J.F., Jr.; Sippy, K.B.; Tietje, K.; Wendt, M.D.; et al. Structure-activity studies for a novel series of tricyclic substituted hexahydrobenz $[e]$ isoindole $\alpha_{1 \mathrm{~A}}$ adrenoceptor antagonists as potential agents for the symptomatic treatment of benign prostatic hyperplasia (BPH). J. Med. Chem. 2000, 43, 1586-1603. [CrossRef] [PubMed]

3. Ventura, S.; Oliver, V.L.; White, C.W.; Xie, J.H.; Haynes, J.M.; Exintaris, B. Novel drug targets for the pharmacotherapy of benign prostatic hyperplasia (BPH). Br. J. Pharmacol. 2011, 163, 891-907. [CrossRef] [PubMed]

4. Kinsella, G.K.; Rozas, I.; Watson, G.W. Computational study of antagonist $/ \alpha_{1 \mathrm{~A}}$ adrenoceptor complexes-Observations of conformational variations on the formation of ligand/receptor complexes. J. Med. Chem. 2006, 49, 501-510. [CrossRef] [PubMed]

5. Handzlik, J.; Szymańska, E.; Wójcik, R.; Dela, A.; Jastrzębska-Więsek, M.; Karolak-Wojciechowska, J.; Fruziński, A.; Siwek, A.; Filipek, B.; Kieć-Kononowicz, K. Synthesis and SAR-study for novel arylpiperazine derivatives of 5 -arylidenehydantoin with $\alpha_{1}$-adrenoceptor antagonistic properties. Bioorg. Med. Chem. 2012, 20, 4245-4257. [CrossRef] [PubMed]

6. Li, M.Y.; Fang, H.; Xia, L. Pharmacophore-based design, synthesis, biological evaluation, and 3D-QSAR studies of aryl-piperazines as $\alpha_{1}$-adrenoceptor antagonists. Bioorg. Med. Chem. Lett. 2005, 15, 3216-3219. [CrossRef] [PubMed]

7. Chen, H.; Liang, X.; Xu, F.; Xu, B.; He, X.; Huang, B.; Yuan, M. Synthesis and cytotoxic activity evaluation of novel arylpiperazine derivatives on human prostate cancer cell lines. Molecules 2014, 19, 12048-12064. [CrossRef] [PubMed]

8. Castiglione, F.; Benigni, F.; Briganti, A.; Salonia, A.; Villa, L.; Nini, A.; Di Trapani, E.; Capitanio, U.; Hedlund, P.; Montorsi, F. Naftopidil for the treatment of benign prostate hyperplasia: A systematic review. Curr. Med. Res. Opin. 2014, 30, 719-732. [CrossRef] [PubMed]

9. Betti, L.; Floridi, M.; Giannaccini, G.; Manetti, F.; Strappaghetti, G.; Tafi, A.; Botta, M. $\alpha_{1}$-Adrenoceptor antagonists. 5. Pyridazinone-arylpiperazines. Probing the influence on affinity and selectivity of both ortho-alkoxy groups at the arylpiperazine moiety and cyclic substituents at the pyridazinone nucleus. Bioorg. Med. Chem. Lett. 2003, 13, 171-173. [CrossRef]

10. Jin, J.; Wang, X.B.; Kong, L.Y. Design, synthesis and biological evaluation of new arylpiperazine derivatives bearing a flavone moiety as $\alpha_{1}$-adrenoceptor antagonists. Bioorg. Med. Chem. Lett. 2011, 21, 909-911. [CrossRef] [PubMed]

11. Abou-Seri, S.M.; Abouzid, K.; Abou El Ella, D.A. Molecular modeling study and synthesis of quinazolinone-arylpiperazine derivatives as $\alpha_{1}$-adrenoreceptor antagonists. Eur. J. Med Chem. 2011, 46, 647-658. [CrossRef] [PubMed]

12. Baran, M.; Kepczyńska, E.; Zylewski, M.; Siwek, A.; Bednarski, M.; Cegła, M.T. Studies on novel pyridine and 2-pyridone derivatives of $N$-arylpiperazine as $\alpha$-adrenoceptor ligands. Med. Chem. 2014, 10, 144-153. [CrossRef] [PubMed]

13. Huang, J.; He, F.; Huang, M.; Liu, X.; Xiong, Y.; Huang, Y.; Zhu, L.; Yang, Y.; Xu, X.; Yuan, M. Novel naftopidil-related derivatives and their biological effects as $\alpha_{1}$-adrenoceptors antagonists and antiproliferative agents. Eur. J. Med. Chem. 2015, 96, 83-91. [CrossRef] [PubMed]

14. Panathur, N.; Gokhale, N.; Dalimba, U.; Koushik, P.V.; Yogeeswari, P.; Sriram, D. New indole-isoxazolone derivatives: Synthesis, characterisation and in vitro SIRT1 inhibition studies. Bioorg. Med. Chem. Lett. 2015, 25, 768-772. [CrossRef] [PubMed] 
15. Alchab, F.; Ettouati, L.; Bouaziz, Z.; Bollacke, A.; Delcros, J.G.; Gertzen, C.G.; Gohlke, H.; Pinaud, N.; Marchivie, M.; Guillon, J.; et al. Synthesis, biological evaluation and molecular modeling of substituted indeno[1,2-b]indoles as inhibitors of human protein kinase CK2. Pharmaceuticals 2015, 8, $279-302$. [CrossRef] [PubMed]

16. Hu, M.J.; Zhang, B.; Yang, H.K.; Liu, Y.; Chen, Y.R.; Ma, T.Z.; Lu, L.; You, W.W.; Zhao, P.L. Design, synthesis and molecular docking studies of novel indole-pyrimidine hybrids as tubulin polymerization inhibitors. Chem. Biol. Drug. Des. 2015. [CrossRef] [PubMed]

17. Paterna, A.; Borralho, P.M.; Gomes, S.E.; Mulhovo, S.; Rodrigues, C.M.; Ferreira, M.J. Monoterpene indole alkaloid hydrazone derivatives with apoptosis inducing activity in human HCT116 colon and HepG2 liver carcinoma cells. Bioorg. Med. Chem. Lett. 2015, 25, 3556-3559. [CrossRef] [PubMed]

18. Romeo, G.; Materia, L.; Manetti, F.; Cagnotto, A.; Mennini, T.; Nicoletti, F.; Botta, M.; Russo, F.; Minneman, K.P. New pyrimido[5,4-b]indoles as ligands for $\alpha_{1}$-adrenoceptor subtypes. J. Med. Chem. 2003, 46, 2877-2894. [CrossRef] [PubMed]

19. Romeo, G.; Materia, L.; Marucci, G.; Modica, M.; Pittalà, V.; Salerno, L.; Siracusa, M.A.; Buccioni, M.; Angeli, P.; Minneman, K.P. New pyrimido[5,4- $b$ ]indoles and [1]benzothieno[3,2- $d$ ]pyrimidines: High affinity ligands for the $\alpha_{1}$-adrenoceptor subtypes. Bioorg. Med. Chem. Lett. 2006, 16, 6200-6203. [CrossRef] [PubMed]

20. Jørgensen, M.; Jørgensen, P.N.; Christoffersen, C.T.; Jensen, K.G.; Balle, T.; Bang-Andersen, B. Discovery of novel $\alpha_{1}$-adrenoceptor ligands based on the antipsychotic sertindole suitable for labeling as PET ligands. Bioorg. Med. Chem. 2013, 21, 196-204. [CrossRef] [PubMed]

21. Nishio, M. CH/ $\pi$ hydrogen bonds in crystals. Cryst. Eng. Comm. 2004, 6, 130-158. [CrossRef]

22. Li, Y.; Liu, Y.; Wang, H.; Xiong, X.; Wei, P.; Li, F. Synthesis, crystal structure, vibration spectral, and DFT studies of 4-aminoantipyrine and its derivatives. Molecules 2013, 18, 877-893. [CrossRef] [PubMed]

23. Al-Omary, F.A.; Mary, Y.S.; Panicker, C.Y.; El-Emam, A.A.; Al-Swaidan, I.A.; Al-Saadi, A.A.; van Alsenoy, C. Spectroscopic investigations, NBO, HOMO-LUMO, NLO analysis and molecular docking of 5-(adamantan-1-yl)-3-anilinomethyl-2,3-dihydro-1,3,4-oxadiazole-2-thione, a potential bioactive agent. J. Mol. Struct. 2015, 1096, 1-14. [CrossRef]

24. Abhishek, K.; Ambrish, K.S.; Shashi, G.; Neeraj, M.; Avijit, M.; Goutam, B. Combined experimental (FT-IR, UV-visible spectra, NMR) and theoretical studies on the molecular structure, vibrational spectra, HOMO, LUMO, MESP surfaces, reactivity descriptor and molecular docking of Phomarin. J. Mol. Struct. 2015, 1096, 94-101.

25. Arshad, M.N.; Bibi, A.; Mahmood, T.; Asiri, A.M.; Ayub, K. Synthesis, crystal structures and spectroscopic properties of triazine-based hydrazone derivatives; a comparative experimental-theoretical study. Molecules 2015, 20, 5851-5874. [CrossRef] [PubMed]

26. De Graaf, C.; Foata, N.; Engkvist, O.; Rognan, D. Molecular modeling of the second extracellular loop of G-protein coupled receptors and its implication on structure-based virtual screening. Molecular modeling of the second extracellular loop of G-protein coupled receptors and its implication on structure-based virtual screening. Proteins 2008, 71, 599-620. [PubMed]

27. Goldfeld, D.A.; Zhu, K.; Beuming, T.; Friesner, R.A. Successful prediction of the intra- and extracellular loops of four G-protein-coupled receptors. Proc. Natl. Acad. Sci. USA 2011, 108, 8275-8280. [CrossRef] [PubMed]

28. Dolomanov, O.V.; Bourhis, L.J.; Gildea, R.J.; Howard, J.A.; Puschmann, H. OLEX2: A complete structure solution, refinement and analysis program. J. Appl. Cryst. 2009, 42, 339-341. [CrossRef]

29. Sheldrick, G.M. A short history of SHELX. Acta. Crystallogr. A 2008, 64, 112-122. [CrossRef] [PubMed]

30. Nakahashi, A.; Yaguchi, Y.; Miura, N.; Emura, M.; Monde, K. A vibrational circular dichroism approach to the determination of the absolute configurations of flavorous 5-substituted-2(5H)-furanones. J. Nat. Prod. 2011, 74, 707-711. [CrossRef] [PubMed]

31. Lu, T.; Chen, F. Multiwfn: A multifunctional wavefunction analyzer. J. Comput. Chem. 2012, 33, 580-592. [CrossRef] [PubMed]

32. Pedretti, A.; Elena Silva, M.; Villa, L.; Vistoli, G. Binding site analysis of full-length $\alpha 1 \mathrm{a}$ adrenergic receptor using homology modeling and molecular docking. Biochem. Biophys. Res. Commun. 2004, 319, 493-500. [CrossRef] [PubMed] 
33. Zhou, H.; Skolnick, J. FINDSITE $(X)$ : A structure-based, small molecule virtual screening approach with application to all identified human GPCRs. Mol. Pharm. 2012, 9, 1775-1784. [CrossRef] [PubMed]

34. Brooks, B.R. CHARMM: A program for macromolecular energy, minimization, and dynamics calculations. J. Comput. Chem. 1983, 4, 187-217. [CrossRef]

35. Krivov, G.G.; Shapovalov, M.V.; Dunbrack, R.L., Jr. Improved prediction of protein side-chain conformations with SCWRL4. Proteins 2009, 77, 778-795. [CrossRef] [PubMed]

36. Trott, O.; Olson, A.J. AutoDock Vina: Improving the speed and accuracy of docking with a new scoring function, efficient optimization, and multithreading. J. Comput. Chem. 2010, 31, 455-461. [CrossRef] [PubMed]

37. Seeliger, D.; de Groot, B.L. Ligand docking and binding site analysis with PyMOL and Autodock/Vina. J. Comput. Aided Mol. Des. 2010, 24, 417-422. [CrossRef] [PubMed]

38. Campbell, A.P.; MacDougall, I.J.; Griffith, R.; Finch, A.M. An aspartate in the second extracellular loop of the $\alpha(1 \mathrm{~B})$ adrenoceptor regulates agonist binding. Eur. J. Pharmacol. 2014, 733, 90-96. [CrossRef] [PubMed]

Sample Availability: Samples of the compounds, indole-arylpiperazine derivatives (1, 2 and 3), are available from the authors.

(C) 2015 by the authors; licensee MDPI, Basel, Switzerland. This article is an open access article distributed under the terms and conditions of the Creative Commons by Attribution (CC-BY) license (http://creativecommons.org/licenses/by/4.0/). 